\title{
日本のICU 看護体制の現状 〜2006年度調査
}

日本集中治療医学会看護部会*

要約：我が国のICU看護体制の実態を知るために，日本集中治療医学会看護部会は全国調査 を行った。看護部会常任委員会・委員会で調査内容を検討した計 31 項目の質問紙を独立行政 法人福祉医療機構情報事業部 WAM NET 事業課サイトで検索した 1,188 施設に郵送し，471施 設, 481 ICUから回答が得られた。ICUベッド数の最頻值は 6 , 総病床数に占める割合は $1.8 \%$, 年間のべ入室患者数中央值は 1,220 人，年間平均在室日数の中央值は 4.4 日であった。 $73.7 \%$ は 一般ICUであり，管理責任医師の所属は麻酔科が最も多かった。 $25.2 \%$ に集中治療を担当する 医師・看護師以外の専従医療専門職者がいたが， 24 時間体制勤務は $10 \%$ 以下であった。 $66.7 \%$

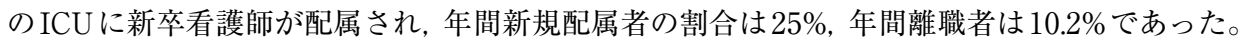
平日日中・夜間ともに約 $80 \%$ の ICUで看護師対患者 $1: 2$ 以上を確保できていた。正確な ICU 在室日数統計量, 信頼できる全国 ICUデータベースの開発, 新規配属看護師の許容割合など の課題が示唆された。

Key words: (1) ICU, (2) nursing, (3) Japan, (4) national survey

\section{はじめに}

集中治療をとりまく環境は, 近年めまぐるしく変化 している。看護においても看護大学の急増や新卒看護 師の早期離職など, 集中治療領域の看護実践に影響が 大きい出来事が多く発生している。そのような中, 我 が国における集中治療領域の看護の実態は, 1986年1) 以降把握されていない。そこで, 日本集中治療医学会 看護部会は, 全国ICUにおける看護体制についての調 査を行った。

\section{方 法}

2006 年 7 月の看護部会常任委員会において, 全国調 査実施が決定され, 調査項目の検討を開始した。看護 部会常任委員会と看護部会委員会において調査項目を 検討し，計 31 項目の質問を作成した。同時に実施す ることとなった身体拘束についての調査とあわせて総 6 頁の冊子体とし, 2007 年 9 月に郵送した。配布先は,
独立行政法人福祉医療機構情報事業部事業課サイト WAM NET内の病院・診療所情報ページ2)から「集中 治療室」を有する施設を検索した結果による1,188施 設である。1施設に複数のICUがある場合は, コピー をして回答するよう依頼文に記載した。

Dillmanの郵送調査法プロトコール3)に従い, 各施 設長およびICU師長あての依頼文には病院名を入れ, 約 3 週間後と約 7 週間後に督促した。1回目の督促は, その時点で「ICUなし」と回答のあった施設を除く全 施設にはがきで実施した。2回目の督促は最初に送っ たアンケート冊子を同封し，その時点で返信のない施 設に実施した。

646施設 (回収率 $54.4 \%$ ) から返信があり, そのうち 147 施設からは「ICUはない」との回答であった。さら に身体拘束のアンケートのみに回答のあった件数を除 き, 最終的に 471 施設からの481件のICUを集計対象 とした。なお, 病院総病床数がICU病床数よりも少な いなど, 疑問のあるデー夕はその項目ごとに除外して

\footnotetext{
*池松 裕子 (名古屋大学医学部保健学科)

道又 元裕 (杏林大学医学部付属病院)

足羽 孝子 (岡山大学病院)
} 


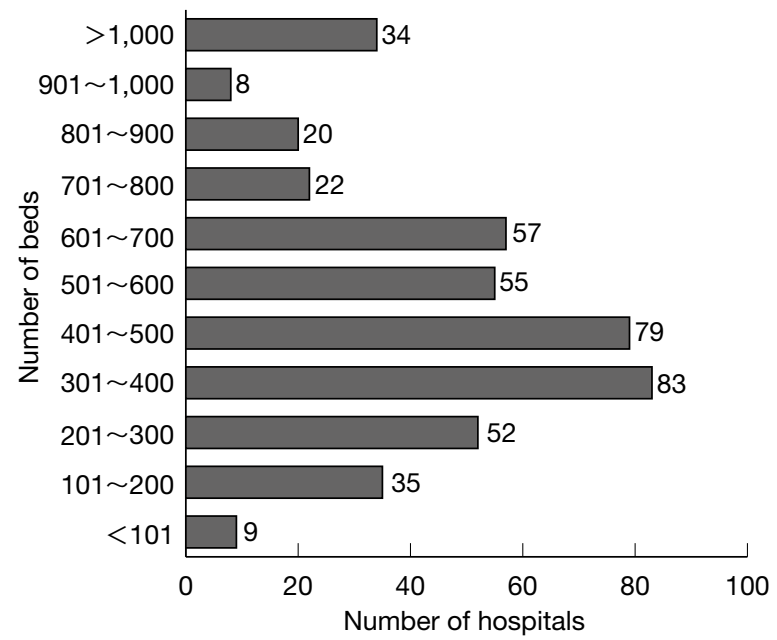

Fig. 1 Number of hospital beds

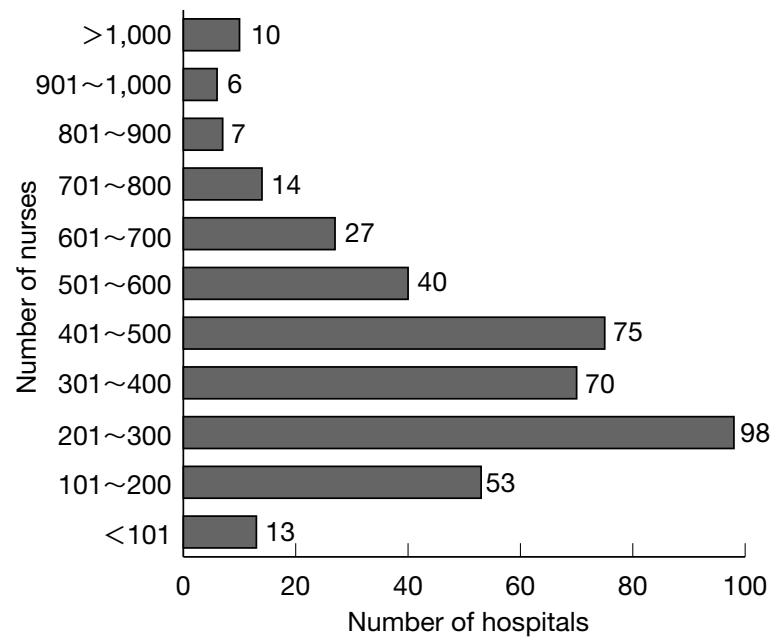

Fig. 2 Number of hospital nurses

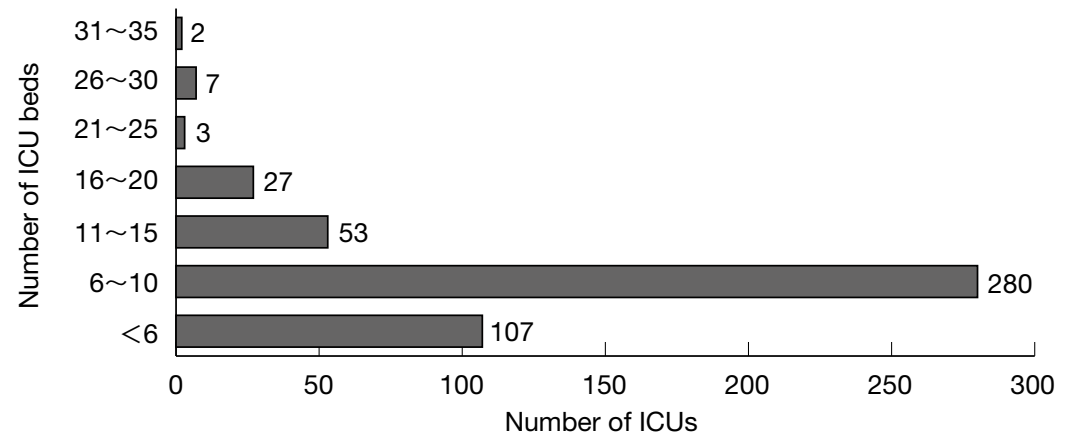

Fig. 3 Number of ICU beds

集計した。集計は，母集団が正規分布していると想定 されるデー夕は平均と標準偏差, していないと想定さ れるデー夕は中央値と最小值・最大值 (必要時最頻 值)にて示した。

\section{調查項目}

調査項目は, (1)施設の概要, (2)ICUの機能および形 態, (3)ICUの管理方式, (4)ICU看護師の人員配置, (5) ICU 看護師への教育支援などであり，入室患者数や 看護師数などは 2006 年 4 月 1 日〜 2007 年 3 月 31 日の 期間に限定した。

\section{結 果}

\section{1）施設の概要}

調查施設 $(n=471)$ の設置母体は地方自治体が 125 施設で最も多く, 医療法人が 104 , 大学法人が 60 , 国 抒よび独立行政法人国立病院機構 58 , 公益法人 43 , 社 会保険関係団体 14 , 厚生連 12 , 企業 9 , その他 (財団法 人, 社団法人, 社会福祉法人など） 41 であった。

施設の総病床数は中央值 458 床 (最小值 41 床, 最大
值 1,505 床), 総看護師数は中央值 354.5 人 (最小值 44 人, 最大值 1,291 人) であった (Fig. 1, Fig. 2)。

\section{2) ICUの機能および形態}

$\operatorname{ICU}(\mathrm{n}=481)$ のベッド数は中央值 7 床 $($ 最小值 1 床, 最大值 31床, 最頻值6床) であった (Fig. 3)。回答 施設の総病床数合計に対するICUベッド数の合計の 割合は $1.8 \%$ であった。年間のべICU入室患者数は中 央值 1,220 人 (最小值 75 人, 最大值 8,082 人), ICU 年間 平均稼働率は中央值 $80 \%$ （最小值 $28 \%$, 最大値 118.9\%)であった。

ICU平均在室日数は中央值 4.4 日（最小值 1 日, 最大 值86日）であり，最大值86日のほかにも 66.2 日という 長い日数も見られたが, これらが記入間違いなのか, 少数の長期入室患者のために平均值が偏移したのか, 判断できなかったため, そのまま使用した。

ICUの種類は 354 件 (73.6\%) が一般（全科）ICUあ るいは一般ICUと他機能との複合ICU と回答した。 単機能ICUの内訳は救命救急センター 28 件, 外科系 ICU 19件, 小児 ICU 7 件, 脳神経 ICU 11件, CCU 14 件，その他が11件であった。 


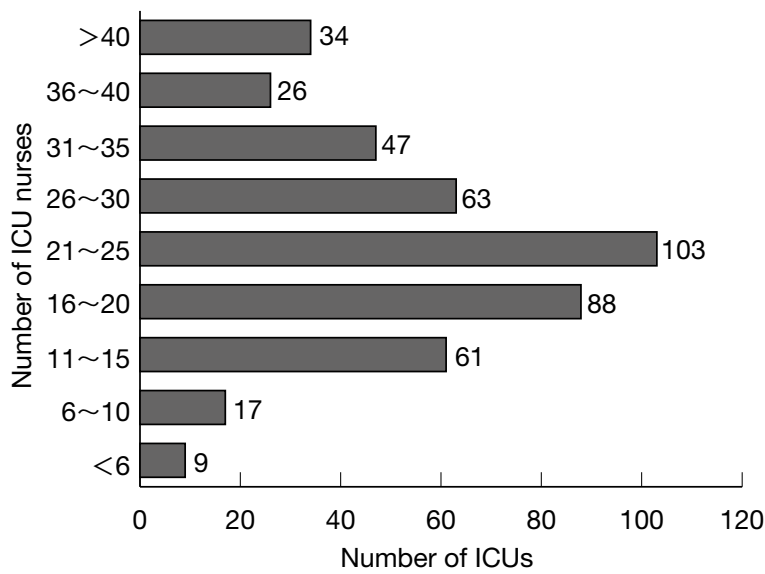

Fig. 4 Number of ICU nurses

\section{3）ICUの管理方式}

ほとんどのICU (442件, 91.9\%)に明確な管理責任 医師が㧍り，その診療科で最も多いのは麻酔科 (167 件), 続いて心藏外科 (53 件), 救急科 ( 42 件), 外科 (38 件), 循環器内科 (36件), 脳外科 (36件) であった。集 中治療科は 7 番目 (24件) であったが, 救急/集中治療 科 (12件) と合わせると 36 件であり, 循環器内科と脳 外科が同数となった。専従医師がいるICUは 243 件 $(50.5 \%) て ゙ ， そ の う ち 114$ 件 $(23.7 \%)$ は医師 1 人で あった。

集中治療を担当する医師・看護師以外の医療専門職 が専従していると回答したのは 121 件 $(25.2 \%)$ で，そ の内訳は理学療法士 15 件 (3.1\%), 臨床工学技士 93 件 (19.3\%)，臨床検查技師 13 件 (2.7\%), 診療放射線技師 10 件 (2.1\%), 薬剤師 35 件 (7.3\%), 管理栄養士8件 (1.7\%)，精神科医 2 件 $(0.4 \%)$ であった。精神リエゾ ン看護師が専従するICUはなかった。上記専従者の うち, 24 時間体制で勤務しているのは, 臨床工学技士 (37 件, $7.7 \%$ ), 臨床検查技師 (9件, $1.9 \%$ ), 薬剤師 (5 件, $1.0 \%$ ), 精神科医 2 件 $(0.4 \%)$, 管理栄養士 (1件, $0.2 \%)$ であった。これらの職種以外で専従しているの は診療情報管理士と医療ソーシャルワーカーがそれぞ れ1件あった。

スタンダードケアプランのあるICUは 409 件 (85.0\%) であり, 情報管理システムは完全電子カルテ が113件 (23.5\%)，オーダリングシステムのみが 234 件 (48.6\%)，まったくinformation technology (IT) 化 していないのは63件 (13.1\%)であった。

面会時間を完全に自由にしているのは49件 (10.2\%)であったが, 時間を決めているという回答 にも,「家族の状況に応じて対応する」や「6:00〜

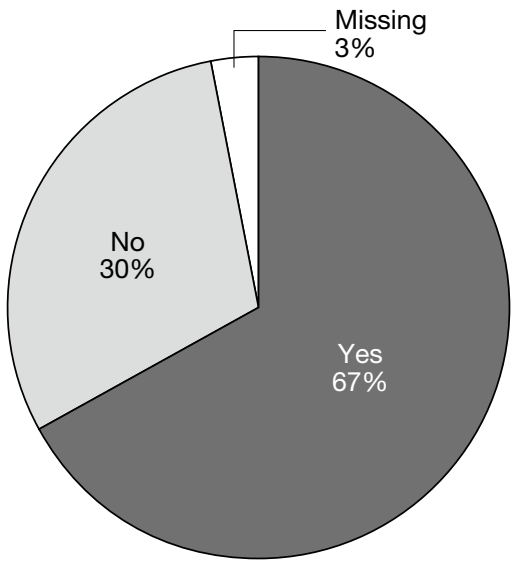

Fig. 5 New graduate nurse employment

21：00」のように，ゆるやかな制限であることを示す 但し書きがいくつかあった。

\section{4) ICU看護師の人員配置}

ICU の所属看護師数は中央值 23 人 (最小値 1 人, 最 大值 95 人) であった (Fig. 4)。なお，所属看護師数が 数百名と書かれたデー夕は除外した。新卒看護師が配 属されるICUは 321 件 (66.7\%)（Fig. 5) で，1年間に配 属される新規配属者 (新卒者, 既卒者, 院内異動含む) は中央值 5 名 (最小值 0 人, 最大值 48 人), 所属看護師 数に対する年間新規配属者の割合は平均 $25.0 \%$ （土18.9\%）であった。1年間の離職者の中央值は 2 人 (最小值 0 人, 最大值 24 人), 所属看護師数に対する年 間離職者の割合は平均 $10.2 \%$ （土11.8\%）であった。

看護師 1 人が担当する患者数は, 平日日中では 1 人 以下が 158 件 $(32.8 \%), 1.1$ 人以上 2 人以下が 265 件 (55.1\%)であった。平日夜間だと 1 人以下 5 件 $(1.0 \%)$, 1.1 人以上 2 人以下は 394 件 $(81.9 \%)$ であり, 4 人以上 も36件 (7.5\%) あった (Fig. 6)。状況に応じた再配置 を行っているのは 277 件 $(57.5 \%)$ であり，そのほとん どは病棟あるいは外来への派遣であった。勤務体制は 三交代制が 353 件 $(73.2 \%)$ であった。

\section{5) ICU看護師への教育支援など}

新卒看護師に対してプリセプターシップを採用して いないと回答したのは4件のみで, 他は採用している, あるいは無回答であった。新卒看護師の夜勤開始時期 は 5 月と 6 月が最も多く, 新卒看護師が配属される ICUのうちの約半数がこの 2 カ月中に開始していた。 4 月から開始のところや, 逆に 3 月から開始のところ もあった (Fig. 7)。

新卒者が配属される ICUの $95 \%$ 超が新卒者向けの 教育プログラムを有していたが,「ない」という回答も 
12 件あった。 $66.9 \%$ ICUに 2 年目以降の教育プログ ラムがあり，長期研修制度があるICUは $52.4 \%$ であっ た。

専門看護師・認定看護師に関する質問は「病院内の 専門看護師」「ICU内の認定看護師」についての問い であったが，回答を見ると専門看護師の種類に $\lceil$ WOC」 (wound, ostomy, continence) や「がん性疼痛」 など認定看護師の呼称があったり，1つのICUに「不 妊看護」や「がん化学療法」などICUとあまり関係のな い認定看護師が 10 人以上書かれていたり，といった 混乱が見られた。また「ACLS」 (advanced cardiovascular life support) や「三学会合同呼吸療法認定士」な ど，いずれでもないタイトルも書かれており，正確な 情報を得ることはできなかった。

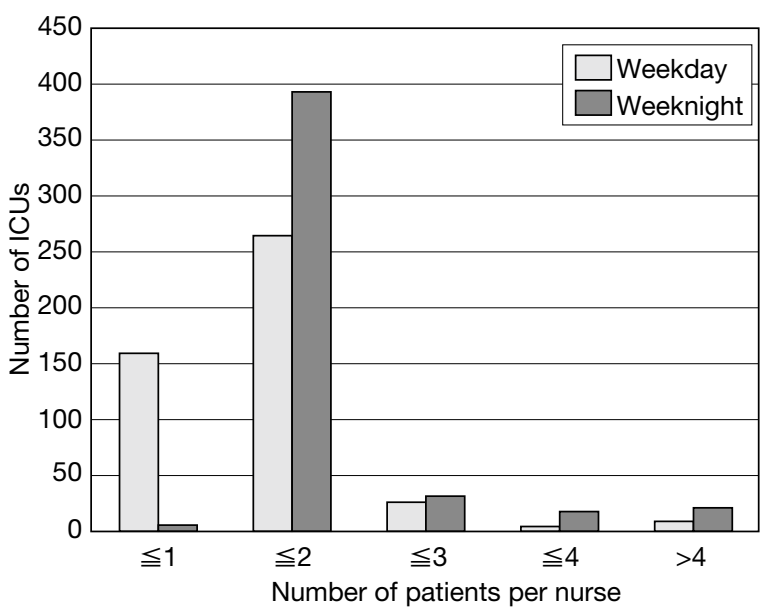

Fig. 6 Nurse-patient ratio

\section{考 察}

本調査において，我が国のICUにおける看護体制の 実情が，一部ではあるが 20 数年ぶりに明らかになっ た。今回の調查では多様なICUを調查することを意 図し, 特定集中治療室管理加算を算定していない施設 (本調查の対象では加算病床数 0 が 56 施設)を含める ために独立行政法人の検索サイトを利用したが, ICU ベッド数 $1 \sim 2$ という回答があり, 病棟内の回復室を ICU と呼んでいる施設が含まれている可能性もあり, データの解釈には注意が必要である。

ICUベッド数が最も多いのは6床であり, 松田班・ 日本集中治療医学会 ICU 機能評価委員会の行った調 查4) と同じであった。1986年の調査では, 平均 7.7 床 と報告されている1訬，このときの分布も正に歪んで いたことが想定されるため, 大きく変わっていないと 考えられる。1 ICUのベッド数については, 設備投資 や維持費の回収のため, および1看護単位として独立 するためには, ある程度以上必要であるが, ベッド数 が多くなればそれだけ業務の複雑性が増し，エラーが 多くなることが考えられる。ベッド数が多いほど与薬 エラーが多いという調査結果5も報告されている。ま た, ベッド数が多いと必然的に看護師数も多くなり, フォーマル・インフォーマルともにコミュニケーショ ンがとりにくくなる。コミュニケーションの不備は, 看護チームのパフォーマンスに影響する。産業界では 5〜10人のチームが理想的だと言われており，それよ りも多人数の看護チームはサブグループを組むことが 提唱されている6)。しかし，ICUではケア時の応援や 急変時の対応など, 不規則に協力して実践することが 多く, 実用的ではない。今後, 事故発生率や経済効率,

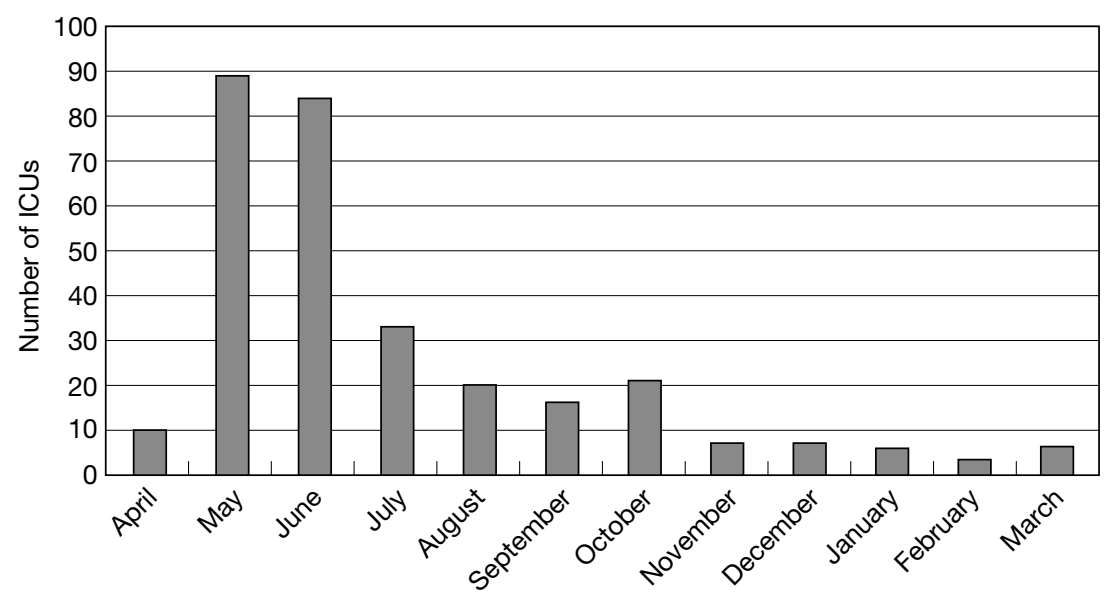

Fig. 7 New graduates starting night shifts 
スタッフの集団力学など, 複数の観点からの至適ベッ ド数の検証が望まれる。

総病床数に対するICUベッド数の割合は $1.8 \%$ であ り, 欧米 8 力国を対象とした調查7) と比較すると, 英 国 (1.2\%)を除く 7 カ国 $(2.5 〜 9 \%)$ を下回っている。 英国の医療システムは, 国民皆保険制度をとっており, 我が国と類似点が多い。ICUベッド数は医療費の gross domestic products (GDP) に占める割合に比例 している7)ことから, 英国では長年医療費抑制政策が とられてきたことが, ICUベッド数にも反映している と考えられる。しかし, 英国では2000年から医療の 近代化を目指して予算が増額され，集中治療に関して は“comprehensive critical care”と呼ばれるプログラ ムが導入された8)。これは集中治療をICUだけでなく, 急性期医療全体で担うことを意図したもので, クリニ カル・ネットワークの創生, outreach serviceの確立, およびケアバンドルの活用から成る8)。Outreach serviceとは, クリティカルケアチームが病棟を巡回 して悪化兆候にある患者を早期発見する制度であ り 9), 英国と同様にICUベッド数の少ない我が国にお いても試みる価值があると思われる。

ICU平均在室日数は 4.4 日であり, 米国のclosed ICU 6.1日, open ICU 9.3日というデータ10)よりも短 かった。我が国では 1977 年が内科系 9.7 日, 外科系 5.1 日, 1981 年が内科系 7.9 日, 外科系 5.4 日, 1984 年が内 科系 8.4 日, 外科系 4.6 日と短縮化してきていた1)が, その後さらに短縮していることがわかる。これは, 医 療技術の発達に加え, せん妄などICU長期滞在による 弊害が注目されるようになったことが関連していると 考えられる。しかし, 本調査を含む多くの調査のICU 平均在室日数の算出法の見直しが必要である。今回, 60 日を超える回答もあり, 長期在室患者が平均值を押 し上げていることが想定される。今後, 中央值や最頻 值, あるいは 1 カ月以上の在室者を除いた平均值の収 集が必要である。

ICUの機能はほとんどが一般ICUであった。欧米諸 国の調査7)でもほぼ同じ比率であるが，その調査は成 人ICUに限定したものである。我が国では小児ICU の少なさが指摘されているが11), 本調查でもわずかで あった。独立した小児ICUの成果は明らかであり 12$)$, 今後増加が望まれる。その際, 看護師の専門性をどの ように考えるか, 検討が必要であろう。現在, 集中ケ ア認定看護師は, 新生児を除きすべての年齢の重症者 看護をカバーしている。今後, 小児ICUが増えれば subspecialtyの必要性を生じる可能性も考えられる。

管理責任者の診療科は, 多くは1986年の調査 ${ }^{1)}$ と同
じく麻酔科であり, 集中治療科という回答は多くな かった。麻酔科や他の診療科であっても集中治療専門 医は数多くおり，十分な知識と技術を備えた専門医が 管理していることも考えられる。どの診療科の医師が ICU 管理責任者として適切であるかは, 今後の論議が 待たれる。

専従医師のいる施設は約半数であった。Closed ICUが在室日数を減らすこと10)や, 治療成績を上げる こと13)は, 欧米では明らかになっているが, 我が国で も検証が待たれる。

約 4 分の 1 の施設で, 集中治療を担当する医師・看 護師以外の医療専門職がICUに専従していた。多職 種チームアプローチが, 医師数の少ないICUにおいて 死亡率を低下させるというデータが米国で示され14), 我が国においても昨今の医師不足の問題に関連し, チーム医療の重要性が注目されている。しかし, 現実 的に専従者を増やすことは人件費の観点から容易なこ とではない。薬剤師の参与が与薬エラーを低減させる ことは検証されている15)が, 他の専門職についても検 証を進める必要がある。特に, ICUにおける超早期離 床が推進されつつある今日 ${ }^{16)}$, 理学療法士の役割はさ らに広がることが期待される。

新卒看護師が配属されるICUは約 3 分の 2 であっ た。ICUに配属される新卒看護師のストレスについて は, しばしば指摘されているが, ICUの離職者の補充 のために一般病棟から多くの看護師が異動すれば,一 般病棟の看護レベルの維持に支障を来たす。したがっ て, 現実的に既卒看護師のみを配属するのは困難であ り，基礎教育を終えたばかりの看護師が多く配属され ていることが明らかになった。現在の基礎看護教育は, 従来の専修学校 3 年間から徐々に 4 年制大学教育へと 移行しつつあるが, 一般教養科目の増加や保健師養成 科目の履修, 在宅看護など, 病院外看護科目の付加に より, 決して臨床看護の履修内容は増えていない。む しろ病院内の看護実習期間は減少している。そのよう な中で, ICUにおける看護に必要な知識・技術・態度 の育成は難しい。そのため, 各施設では新卒者オリエ ンテーションおよび指導に多大なエネルギーを費やし ている。施設側では卒後臨床研修制度の導入など, 新 たな対応策を講じており, 新卒ICU入職者オリエン テーションの標準化なども考慮する必要がある。一方, 基礎教育サイドを考えると, 大学はカリキュラムの自 由度が高く, 各自の特色を出すことが可能である。特 色として急性期看護を強化したカリキュラムを組む大 学が増加するよう, かつてAmerican Association of Critical-Care Nurses (AACN) が行ったような行動も 
必要ではないか。

我が国のICU 看護師の約 4 分の 1 がICU 経験 1 年未 満であることが明らかになった。年間の新規配属者が 離職者を大きく上回ったのは, 本調査では新規配属者 には異動者を含め, 離職者には含めなかったことと, 新設ICUが含まれているためと推測される。一般病 棟における臨床経験があったとしても, ICUでの看護 は習得すべき知識・技術が膨大であり, 重症患者への 看護ケアの質が保証できているかが懸念される。今後, 看護師の経験年数構成と看護ケアの質との関係につい て検証し, 許容される新規配属者の割合が明らかにさ れることが望まれる。

ICU 看護師は他部署と比べて不安が大きく ${ }^{17)}$, 異動 者のストレスも指摘されている18)。異動者はその多 様な背景から, 新卒者のような統一された教育プログ ラムは適用しにくい。中には自身の意思に反して異動 になった看護師もおり，そのような心理面も含めた指 導・支援体制が求められる。今後, 複数の施設の試み や多くの事例を集約し, 個別的な対応を促進できるモ デルの開発が必要である。

1 人の看護師が担当する患者数は, ほとんどの ICU で昼夜ともに 2 人以下を維持できていた。ICUの看護 人員が多いことは, 合併症の発現率やコスト 19), 与薬 エラー5)などを低減することが示唆されているもの の, 死亡率においては統計学的に有意な結果は得られ ていない19),20)。しかし, 看護ケアの目的は救命や事 故防止だけではないため, 生命の危機に瀕した患者が できる限り安らかな気持ちで過酷な療養生活を過ごす ことができる, あるいは尊厳ある死を迎えることがで きるための人員が必要である。看護の目的に沿った質 の高い看護の提供に適した看護師数の再検討が今後求 められる。

看護師の数は多いほど良いことは言うまでもない が, ICUの患者数には変動がある。満床時を想定した 看護師数を定員とすると, それより少ない患者数の場 合の対応に苦慮していることがうかがえる。他部署へ の応援が最も多い回答であったが, 臨時の応援勤務は ストレスが高いことも示唆されており, ICU看護師と してのアイデンティティや士気への影響も考えられ る。看護師の最大の役割がベッドサイドケアであるこ とは異論のないところであるが, その向上のための研 究活動も業務として認められれば, 余剰人員の業務割 り当てに苦慮することもなく, またICU看護の質向上 を果たせるのではないかと考える。しかし，これには ICUのみでなく, 病院あるいは社会全体の看護専門職 に対する認識の改革が必要である。
全国的な傾向として, 看護師の交代勤務は三交代か ら二交代へと移行しつつあるが, 本調査の時点では二 交代のICUのほうが少なかった。一般病棟の調査で は, 三交代よりも二交代のほうが, 蓄積疲労が軽度で あったという報告21)や, 16 時間勤務において倦怠感 が三交代よりも低いという報告 22$)$ があるが, 後者にお いては 16 時間勤務中 2 時間の仮眠をとっていること や, 16 時間勤務での身体活動が三交代に比べて少ない というデータも考慮に入れる必要がある。一般病棟と 比べて昼夜の業務内容の違いが少なく, 仮眠をとる保 証ができないICUにおいて，いずれの勤務形態が望ま しいのか, 検証が必要であろう。加えて, 米国では長 時間勤務 (>12.5 時間) と夜間勤務が居眠り運転のリ スクを有意に高めることが明らかになっており 23), 勤 務時間外の生活をも含めて検討する必要があるであろ う。

ICU内の情報テクノロジー化は多くの施設で進んで いるようであった。スタンダードケアプランも広く普 及している。しかし，それらのプランを客観的に評価 した論文はそしく，各施設での経験を集約・検証し， エビデンスに基づいたケアプランの策定が望まれる。

ICUにおける面会は自由化が推奨されて久しいが, 完全に自由としている施設はわずかであった。ICUの 面会時間については多くの報告があるが, いずれも 1 施設における少数の変数に基づくものであり, 総合的 な評価に至っていない。患者・家族の権利として時間 制限を撤廃するのも一つの主張であろうが, 質の高い エビデンスが望まれる。

新卒者に対するプリセプターシップは, 一時弊害も 指摘されていたが, 今回調査したほとんどのICUで採 用していることから, 利点が上回っていると解釈でき る。プリセプターシップに関する研究も, 一時より減 少し24), 定着してきたことが推察できる。

専門看護師・認定看護師については混乱した回答が 多く, 有用な情報を得ることができなかった。院内と ICU内とを混同したと思われる回答もあったが, 専門 看護師と認定看護師の区別ができていないことを示唆 する回答もあった。専門看護師・認定看護師は制定か ら 10 数年が経ち, 両者あわせて登録者 6,000 人を超え ているが, 全国的な認知度はいまだ十分ではないと言 える。専門看護師と認定看護師の活用については最近 でもしばしば話題になっており, 看護管理者の正しい 理解を促進する活動が必要である。

本調査の最大の反省点は, アンケート依頼文に ICU を明確に定義しなかったことである。そのため, 外科 病棟内の術後回復室と思われる回答が混在した。ICU 
のUはunitであり,「単位」という意味であるが，日本 語では集中治療「室」と，1つの病室とも解釈できる表 現である。今後, 医療界でのコミュニケーションに支 障が出ないよう, 何らかの対策を講じる必要があるか もしれない。

また，検索に用いたWAM NETでは，「厚生労働省 の全国の病院・診療所データから検索できます」2) と 標榜してあるため, 信頼性が高いと判断して使用した が,「ICUなし」との回答も多く見られた。今後, より 信頼性の高い全国ICUデータベースの構築が望まれ る。加えて, ICUのない病院に打ける重症患者管理に ついての調查も必要であろう。これらの病院において も，入院中に急変あるいは状態悪化のために集中的な 全身管理が必要となる患者は少なからずいるはずであ る。そのような患者は, 誰がどこでどのように管理し ているのか，あるいはすぐに転院できるような関連施 設があるのか，把握する必要があると考える。

\section{おわりに}

日本集中治療医学会看護部会として, 全国のICU お よびその看護について概要を調査した。今回は, ICU の概要についての調查のみで, 看護の内容までは調查 できていない。本調查で明らかになったことに基づき, 要因探索研究やアウトカム研究を行い, 徐々にエビデ ンスの確立へと発展していくことを期待したい。

\section{謝 辞}

本調查にあたり，御協力いただきました調查対象施設の 方々，ならびに調查項目の設定や実施方法に貴重な助言をい ただきました平成 $17 〜 19$ 年度, $20 〜 21$ 年度看護部会常任委 員・委員の皆さまに厚く御礼申し上げます。

\section{文 献}

1) 山崎慶子, 上泉和子，高橋定子，他．日本に扔ける集中治 療・看護の現状. ICU と CCU 1986;10:1035-44.

2) 独立行政法人福祉医療機構. WAM NET. 病院 - 診療所情 報. Available from: http://www.wam.go.jp/iryo/ [accessed December 31, 2010]

3) Catanzaro M. Implementing questionnaires and interviews. In: Woods NF, Catanzaro M. editors. Nursing Research: theory and practice. St. Louis: C.V. Mosby; 1988.p. 316-33.

4) ICU 機能評価委員会，今中雄一，林田賢史，他. わが国集 中治療室の現状調查 一松田班調查結果報告一. 日集中医誌 2010;17:227-32.

5) Valentin A, Capuzzo M, Guidet B, et al; Research Group on Quality Improvement of the European Society of Intensive Care Medicine (ESICM); Sentinel Events Evaluation (SEE) Study Investigators. Errors in administration of parenteral drugs in intensive care units: multi- national prospective study. BMJ 2009;338:b814.

6) Kalisch BJ, Begeny SM. Improving nursing unit teamwork. J Nurs Adm 2006;35:550-6.

7) Wunsch H, Angus DC, Harrison DA, et al. Variation in critical care services across North America and Western Europe. Crit Care Med 2008;36:2787-93.

8) Hutchings A, Durand MA, Grieve R, et al. Evaluation of modernization of adult critical care services in England: time series and cost effectiveness analysis. BMJ 2009; 339:b4353.

9) Watson W, Mozley C, Cope J, et al. Implementing a nurse-led critical care outreach service in acute care hospital. J Clin Nurs 2006;15:105-10.

10) Society of Critical Care Medicine. Critical Care Statistics in the United States. Available from: http://www.sccm. org/Documents/WebStatisticsPamphletFinalJune07.pdf [accessed September 7, 2010]

11）日本集中治療医学会集中治療部設置基準検討委員会，日本 集中治療医学会新生児・小児集中治療委員会, 日本小児科 学会小児医療改革・救急プロジェクトチーム, 厚生労働科 学研究費補助金医療技術評価総合研究事業小児医療におけ る安全管理指針の策定に関する研究班. 小览集中治療部設 置のための指針 一 2007 年 3 月一. 日集中医誌 $2007 ; 14$ : 627-38.

12) 桜井淑男, 田村正德. 我が国における小児集中治療の有効 性と今後の展望. 日集中医誌 2007:14:53-6.

13) Pronovost PJ, Angus DC, Dorman T, et al. Physician staffing patterns and clinical outcomes in critically ill patients: a systematic review. JAMA 2002; 288:2151-62.

14) Kim MM, Barnato AE, Angus DC, et al. The effect of multidisciplinary care teams in intensive care unit mortality. Arch Intern Med 2010;170:369-76.

15) Leape LL, Cullin DJ, Clapp MD, et al. Pharmacist participation on physician rounds and adverse drug events in the intensive care unit. JAMA 1999;282:267-70.

16) Hopkins RO, Spuhler VJ. Strategies for promoting early activity in critically ill mechanically ventilated patients. AACN Adv Crit Care 2009;20:277-89.

17) Kawano Y. Association of job-related stress factors with psychological and somatic symptoms among Japanese hospital nurses: effect of departmental environment in acute care hospitals. J Occup Health 2008;50:79-85.

18) 畑中保子, 山形聡子, 井上佳代子. 集中治療室に配置転換 した看護師のストレスの要因調査. 日看会論集：看管理 2004:35:6-8.

19) Amaravadi RK, Dimick JB, Pronovost PJ, et al. ICU nurse-to-patient ratio is associated with complications and resource use after esophagectomy. Intensive Care Med 2000;26:1857-62.

20) Kiekkas P. Sakellaropoulos GC, Brokalaki H, et al. Association between nursing workload and mortality of intensive care unit patients. J Nurs Scholarsh 2008;40: 385-90.

21) 中山晃志, 佐藤和子. 看護職の交代勤務の形態と蓄積的疲 労の関係. 看管理 2004;14:408-11.

22) Fukuda H, Takahashi M, Arito H. Nurses' workload associated with 16-h night shifts on the 2-shift system. I: Comparison with the 3-shift system. Psychiatry Clin Neurosci 1999;53:219-21.

23) Scott LD, Hwang WT, Rogers AE, et al. The relationship between nurse work schedules, sleep duration, and drowsy driving. Sleep 2007;30:1801-7.

24）室伏圭子，豊嶋三枝子．プリセプターシップに関する研究 の動向と課題 (2001-2005)。獨協医大看紀 2007;1:60-7. 


\section{Abstract}

\section{Current status of ICU nursing in Japan in 2006}

\section{The Japanese Society of Intensive Care Medicine, Nursing Division}

The Nursing Division of the Japanese Society of Intensive Care Medicine has conducted a national survey to obtain data on nursing in ICUs. A 31-item questionnaire was generated by the standing committee members and local chapter representatives and was sent to 1,188 hospitals. Four hundred and eighty-one ICUs from 471 hospitals replied. The mode of the number of ICU beds was 6 . The proportion of ICU beds to all hospital beds was $1.8 \%$. The median number of annual ICU admissions was 1,220 patients, and the median number of average length of stay was 4.4 days. Threequarters of the ICUs were general ICUs, and most of the medical directors were affiliated with anesthesiology. Health care professionals other than critical care nurses or physicians were employed in one-quarter of the surveyed ICUs, but less than $10 \%$ of the ICUs employed these personnel in round-the-clock shifts. New graduate nurses were assigned to two-thirds of the ICUs. New employee nurses accounted for $25 \%$ of the nurses in the ICU annually. The annual turnover rate was $10 \%$. The nurse-patient ratio was $1: 2$ or less in more than $80 \%$ of the ICUs on weekdays and nights. The results of the questionnaire implied a need of more accurate statistics of length of ICU stay, development of reliable ICU database, and determination of acceptable proportion of new employed nurses.

Key words: (1) ICU, (2) nursing, (3) Japan, (4) national survey

J Jpn Soc Intensive Care Med 2011;18:433 440. 